Nevada

Environmental

Restoration

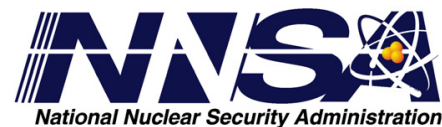

Project

\title{
Addendum to the Closure Report for Corrective Action Unit 423: \\ Area 3 Building 03-60 \\ Underground Discharge Point, \\ Tonopah Test Range, Nevada
}

Controlled Copy No.:

Revision No.: 0

October 2008

Approved for public release; further dissemination unlimited.

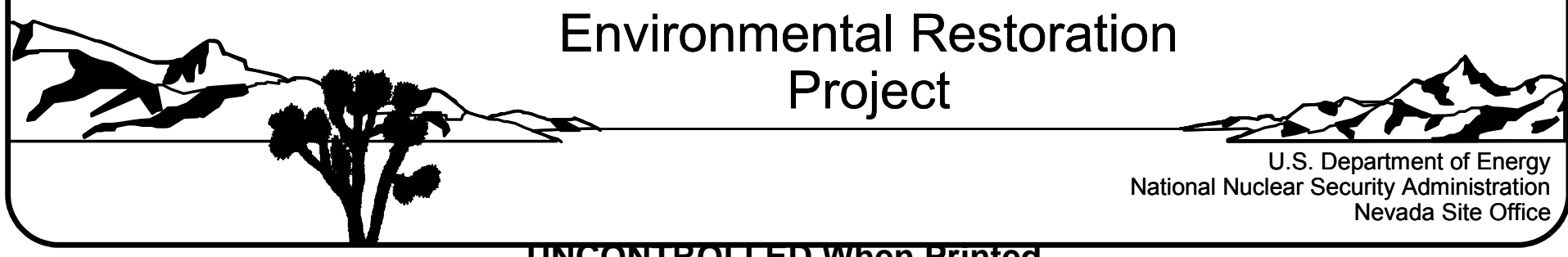


Available for public sale, in paper, from:

U.S. Department of Commerce

National Technical Information Service

5285 Port Royal Road

Springfield, VA 22161

Phone: 800.553 .6847

Fax: 703.605.6900

Email: orders@ntis.gov

Online ordering: http://www.ntis.gov/ordering.htm

Available electronically at $\underline{h t p: / / w w w . o s t i . g o v / b r i d g e ~}$

Available for a processing fee to U.S. Department of Energy and its contractors, in paper, from:

U.S. Department of Energy

Office of Scientific and Technical Information

P.O. Box 62

Oak Ridge, TN 37831-0062

Phone: 865.576 .8401

Fax: 865.576.5728

Email: reports@adonis.osti.gov

Reference herein to any specific commercial product, process, or service by trade name, trademark, manufacturer, or otherwise, does not necessarily constitute or imply its endorsement, recommendation, or favoring by the United States Government or any agency thereof or its contractors or subcontractors. 


\title{
ADDENDUM TO THE CLOSURE REPORT FOR CORRECTIVE ACTION UNIT 423: \\ AREA 3 BUILDING 03-60 UNDERGROUND DISCHARGE POINT, TONOPAH TEST RANGE, NEVADA
}

\author{
U.S. Department of Energy \\ National Nuclear Security Administration \\ Nevada Site Office \\ Las Vegas, Nevada
}

Controlled Copy No.:

Revision No.: 0

October 2008

Approved for public release; further dissemination unlimited. 


\section{Addendum to the Closure Report for Removal of the Use Restriction}

This document constitutes an addendum to the July 1999, Closure Report for Corrective Action Unit 423: Area 3 Building 0360 Underground Discharge Point, Tonopah Test Range, Nevada as described in the document Recommendations and Justifications for Modifications for Use Restrictions Established under the U.S. Department of Energy, National Nuclear Security Administration Nevada Site Office Federal Facility Agreement and Consent Order (UR Modification document) dated February 2008. The UR Modification document was approved by NDEP on February 26, 2008. The approval of the UR Modification document constituted approval of each of the recommended UR modifications. In conformance with the UR Modification document, this addendum consists of:

- This cover page that refers the reader to the UR Modification document for additional information

- The cover and signature pages of the UR Modification document

- The NDEP approval letter

- The corresponding section of the UR Modification document

This addendum provides the documentation justifying the cancellation of the UR for CAS 03-02-002-0308, Underground Discharge Point. This UR was established as part of a Federal Facility Agreement and Consent Order (FFACO) corrective action and is based on the presence of contaminants at concentrations greater than the action levels established at the time of the initial investigation (FFACO, 1996; as amended August 2006).

Since this UR was established, practices and procedures relating to the implementation of risk-based corrective actions (RBCA) have changed. Therefore, this UR was re-evaluated against the current RBCA criteria as defined in the Industrial Sites Project Establishment of Final Action Levels (NNSA/NSO, 2006c). This re-evaluation consisted of comparing the original data (used to define the need for the UR) to risk-based final action levels (FALs) developed using the current Industrial Sites RBCA process.

The re-evaluation resulted in a recommendation to remove the UR because contamination is not present at the site above the risk-based FALs. Requirements for inspecting and maintaining this UR will be canceled, and the postings and signage at this site will be removed. Fencing and posting may be present at this site that are unrelated to the FFACO UR such as for radiological control purposes as required by the $N V / Y M P$ Radiological Control Manual (NNSA/NSO, 2004f). This modification will not affect or modify any non-FFACO requirements for fencing, posting, or monitoring at this site. 
Nevada

Environmental

Restoration

Project

Recommendations and Justifications for Modifications for Use Restrictions Established under the U.S. Department of Energy, National Nuclear Security Administration Nevada Site Office

Federal Facility Agreement and Consent Order

Controlled Copy No.:

Revision No.: 0

February 2008

Approved for public release; further dissemination unlimited.

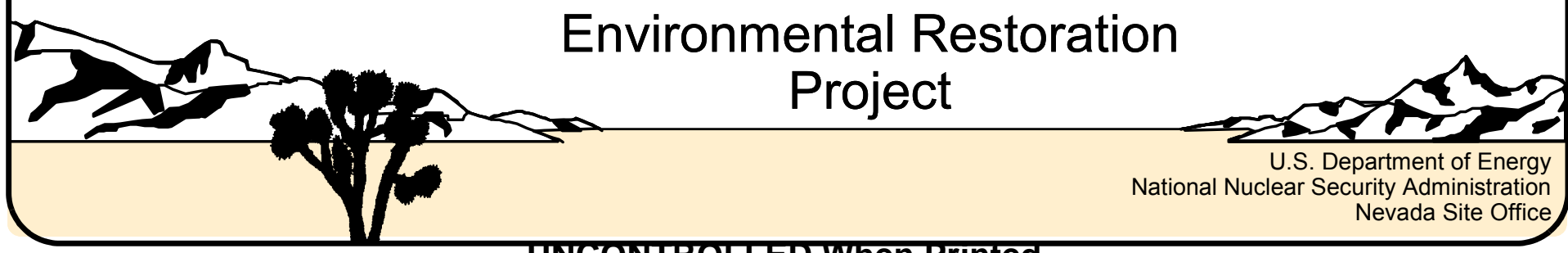


Recommendations and Justifications for Modifications for Use Restrictions Established under the U.S. Department of Energy, National Nuclear Security Administration Nevada Site Office Federal Facility Agreement and Consent Order

Approved by: /s/ Kevin J. Cabble

Date: $02 / 05 / 2008$

Kevin J. Cabble

Federal Sub-Project Director

Industrial Sites Sub-Project

Approved by:

/s/ John B. Jones

Date: $02 / 04 / 2008$

John B. Jones

Acting Federal Project Director

Environmental Restoration Project 
February 26, 2008

John B. Jones

Acting Federal Project Director

Environmental Restoration Project

National Nuclear Security Administration

Nevada Site Office

P. O. Box 98518

Las Vegas, NV 89193-8518

RE: Approval of Recommendations and Justifications for Modifications for Use Restrictions

Established under the U.S. Department of Energy, National Nuclear Security Administration, Nevada Site Office Federal Facility Agreement and Consent Order

Dear Mr. Jones:

The Nevada Division of Environmental Protection, Bureau of Federal Facilities (NDEP) staff has received and reviewed the February 2008 final report for Recommendations and Justifications for Modifications for Use Restrictions Established under the U.S. Department of Energy, National Nuclear Security Administration, Nevada Site Office. The NDEP approves the requested changes to the previously agreed upon use restrictions for those Corrective Action Sites (CASs) as described in the report.

Address any questions regarding this matter to either Ted Zaferatos at (702) 486-2850, ext. 234 , or me at (702) 486-2850, ext. 231.

Sincerely

\section{/s/ Tim Murphy}

\section{T.H. Murphy}

Chief

Bureau of Federal Facilities

$\mathrm{TZ}$

cc: $\quad$ E.F. DiSanza, WMP, NNSA/NSO

FFACO Group, PSG, NNSAINSO, Las Vegas, NV

David C. Loewer, DTRAVCXT1, M/S 645, Mercury, NV

W.R. Griffin, SNJV/DTRA, M/S 645, Mercury, NV

T.A. Thiele, NSTec, Las Vegas, NV

R.F. Boehlecke, SNJV, Las Vegas, NV

K. J. Cabble, ERP, NNSANSO, Las Vegas, NV

John Wong. Jeff MacDougall, Dennis Nicodemus, NDEP Las Vegas, NV 


\subsection{CAU 423, CAS 03-02-002-0308 - Underground Discharge Point}

\subsection{CAS Description}

Corrective Action Unit 423 consists of one CAS located in Area 3 at the TTR. Corrective Action Site 03-02-002-0308 consists of the Underground Discharge Point (UDP) and its associated discharge pipeline extending from Building 03-60, the Auto Maintenance Shop. From approximately 1965 to 1990 , the gravity-fed discharge pipeline carried waste oil and other shop products to the UDP. The UDP is $240 \mathrm{ft}$ northwest of the northwest corner of Building 03-60 and is adjacent to a barbed-wire fence near the southwest corner of the Area 3 Boxcar Storage Yard. The UDP consists of a 3.5-ft diameter corrugated metal culvert pipe, which is set vertically in the ground at a depth of $1.5 \mathrm{ft}$ bgs $(\mathrm{DOE} / \mathrm{NV}, 1999 \mathrm{a})$.

\subsection{Current Use Restriction Description}

The future use of any land affected by this UR is restricted from any DOE or Air Force activity that may alter or modify the containment control, as approved by the state and identified in the CAU CR or other CAU documentation, unless appropriate concurrence is obtained in advance. An asymmetrical petroleum hydrocarbon plume, measuring $35 \mathrm{ft}$ in length, $20 \mathrm{ft}$ in width, and 14 to $65 \mathrm{ft}$ in depth, has formed beneath the UDP and migrated westward. A UR was implemented restricting excavation of the area, including the removal of Building 03-60, or excavation of areas impacted by the UDP petroleum hydrocarbon plume, including the discharge pipe leading from Building 03-60. Post-closure monitoring is required and consists of biannual inspections and an annual report containing the inspection checklists (DOE/NV, 1999a).

\subsection{Basis for Current Use Restriction}

A total of 38 soil samples were collected and submitted for laboratory analysis. Samples were analyzed for total VOCs, total SVOCs, total PCBs, total RCRA metals, and TPH (diesel and gasoline). A plume of TPH greater than the PAL of $100 \mathrm{mg} / \mathrm{kg}$ was identified with a maximum dimension of 6 by $11 \mathrm{~m}$ and ranges in depth from a minimum of 4 to $20 \mathrm{~m}$. The plume is asymmetric and primarily west of and below the UDP. With the exception of arsenic, the PALs were not exceeded for total VOCs, total SVOCs, total PCBs, and total RCRA metals for any of the samples collected from the subsurface at the Building 03-60 UDP site. The concentrations of arsenic above the PAL of $2.7 \mathrm{mg} / \mathrm{kg}$ were within the range considered representative of ambient conditions at the site. Therefore, arsenic is not considered to be a basis for this UR. 
Radiological field screening did not detect radiation that was distinguishable from background activities (DOE/NV, 1998b).

Table 24-1 contains analytical results of all COCs at CAS 03-02-002-0308 that are the basis for the current UR. The sample matrix for all samples is soil.

Table 24-1

Sample Results for COCs at CAS 03-02-002-0308 Used To Establish Current Use Restriction

\begin{tabular}{|c|c|c|c|c|}
\hline \multirow{2}{*}{ Borehole No. } & Sample ID & $\begin{array}{c}\text { Sample Depth } \\
\text { (ft bgs) }\end{array}$ & TPH (DRO) & TPH (GRO) \\
\cline { 4 - 5 } & & & $\begin{array}{c}\mathbf{P A L} \\
\mathbf{1 0 0} \mathbf{~} \mathbf{g} / \mathbf{k g}\end{array}$ & $\begin{array}{c}\mathbf{P A L} \\
\mathbf{1 0 0} \mathbf{~} \mathbf{g} / \mathbf{k g}\end{array}$ \\
\hline \hline B1 & TTR01103 & 30 & 2,000 & 560 \\
\hline B1 & TTR01104 & 45 & 1,700 & 430 \\
\hline B6 & TTR01131 & 20 & 2,400 & 640 \\
\hline B6 & TTR01132 & 30 & 1,400 & 550 \\
\hline B6 & TTR01133 & 45 & 1,400 & 670 \\
\hline B6 & TTR01134 & 60 & 1,800 & $760(\mathrm{~J})$ \\
\hline B6 & TTR01137 & 90 & -- & 1,400 \\
\hline B8 & TTR01147 & 35 & 110 & -- \\
\hline B8 & TTR01149 & 60 & 520 & -- \\
\hline \hline
\end{tabular}

bgs $=$ Below ground surface

$\mathrm{DRO}=$ Diesel-range organics

ID = Identification

$\mathrm{ft}=$ Foot

$\mathrm{mg} / \mathrm{kg}=$ Milligrams per kilogram

PAL $=$ Preliminary action level

$\mathrm{GRO}=$ Gasoline-range organics

$\mathrm{TPH}=$ Total petroleum hydrocarbons

$\mathrm{J}=$ Estimated value

$--=$ No detects above action levels

\subsection{Basis for Use Restriction Modification}

The UR included both the UDP and the associated piping based on the characterization sample results from the UDP. Because piping discharged directly into the UDP, it is reasonable to assume that even if there was any leakage from the piping, contaminants concentrations from any potential piping leak would not exceed concentrations found in the UDP. The samples with the maximum concentrations of TPH from the UDP have no TPH-related contaminant concentrations above their corresponding PALs.

The revised FALs associated with the TPH contamination were established based on the PALs of hazardous constituents of TPH diesel as described in Section 2.2.2. Hazardous constituents of TPH diesel were not detected in any of the samples at concentrations greater than their respective 
PALs (DOE/NV, 1998b). Therefore, no contaminants are present at this site in concentrations exceeding the revised FALs, and all revised FALs were established at the PAL concentrations.

\subsection{Proposed Modification}

Remove the FFACO UR, associated fencing and postings, and monitoring requirements from this site. 


\section{References}

DOE/NV, see U.S. Department of Energy, Nevada Operations Office.

FFACO, see Federal Facility Agreement and Consent Order.

Federal Facility Agreement and Consent Order. 1996 (as amended). Agreed to by the State of Nevada; U.S. Department of Energy, Environmental Management; U.S. Department of Defense; and U.S. Department of Energy, Legacy Management.

NNSA/NSO, see U.S. Department of Energy, National Nuclear Security Administration Nevada Site Office.

U.S. Department of Energy, National Nuclear Security Administration Nevada Site Office. 2004f. NV/YMP Radiological Control Manual, DOE/NV--11718-079, Rev. 5. Prepared by Bechtel Nevada. Las Vegas, NV.

U.S. Department of Energy, National Nuclear Security Administration Nevada Site Office. 2006c. Industrial Sites Project Establishment of Final Action Levels, Rev. 0, DOE/NV--1107. Las Vegas, NV.

U.S. Department of Energy, Nevada Operations Office. 1998b. Corrective Action Decision Document for Corrective Action Unit 423: Building 03-60 Underground Discharge Point, Tonopah Test Range, Nevada, Rev. 0, DOE/NV--508, UC-700. June. Las Vegas, NV.

U.S. Department of Energy, Nevada Operations Office. 1999a. Closure Report for Corrective Action Unit 423: Area 3 Building 03-60 Underground Discharge Point, Tonopah Test Range, Nevada, Rev. 0, DOE/NV--253. July. Las Vegas, NV. 


\section{Library Distribution List}

\section{$\underline{\text { Copies }}$}

U.S. Department of Energy

National Nuclear Security Administration

Nevada Site Office

Technical Library

P.O. Box 98518, M/S 505

Las Vegas, NV 89193-8518

U.S. Department of Energy

Office of Scientific and Technical Information

P.O. Box 62

Oak Ridge, TN 37831-0062

Southern Nevada Public Reading Facility

c/o Nuclear Testing Archive

P.O. Box 98521, M/S 400

Las Vegas, NV 89193-8521

Manager, Northern Nevada FFACO

Public Reading Facility

c/o Nevada State Library \& Archives

100 N Stewart Street

Carson City, NV 89701-4285
1 (Uncontrolled, electronic copy)

1 (Uncontrolled, electronic copy)

2 (Uncontrolled, electronic copies)

1 (Uncontrolled, electronic copy) 